A Journal of Culture, English Language, Teaching \& Literature ISSN 1414-3320 (Print), ISSN 2502-4914 (Online)

Vol. 18 No.2; December 2018

Copyright () Soegijapranata Catholic University, Indonesia

Promoting EFL Student Teachers' Life-Long Learning through Microteaching Lesson Study

${ }^{1}$ Fitri Budi Suryani, ${ }^{2}$ Dwi Rukmini, ${ }^{3}$ Dwi Anggani

${ }^{4}$ Linggar Bharati, and ${ }^{5}$ Rudi Hartono

1,2,3,4.English Education Program, Post Graduate Study, Universitas Negeri Semarang, Semarang, Indonesia

email: ${ }^{1}$ fitri.budi@umk.ac.id; ${ }^{2}$ wiwidwirukmini@yahoo.com, 33wi_anggani@yahoo.com; ${ }^{4}$ rudi_fbsunnes@yahoo.com

Received: 15-11-2017

Accepted: 14-04-2018 Published: 23-12-2018 


\title{
Promoting EFL Student Teachers' Life-Long Learning through Microteaching Lesson Study
}

\author{
${ }^{1}$ Fitri Budi Suryani, ${ }^{2}$ Dwi Rukmini, ${ }^{3}$ Dwi Anggani \\ ${ }^{4}$ Linggar Bharati, and ${ }^{5}$ Rudi Hartono \\ ${ }^{1}$ fitri.budi@umk.ac.id; ${ }^{2}$ wiwidwirukmini@yahoo.com, \\ 33wi_anggani@yahoo.com; ${ }^{4}$ rudi_fbsunnes@yahoo.com \\ 1,2,3,4English Education Program, Post Graduate Study, \\ Universitas Negeri Semarang, Semarang, Indonesia
}

\begin{abstract}
The success of lesson study as an approach for teacher professional development in improving students' learning has inspired the works on microteaching lesson study which is designed for student teachers in microteaching course. Some studies show that microteaching lesson study brought about positive result to student teachers' pedagogical ability and content knowledge. However, that microteaching lesson study influences student teachers in their teaching internship, that is the course taken after microteaching where student teachers teach real students in real schools, has not been revealed yet. This study aims at exploring the influence of microteaching lesson study on the English as a Foreign Language (EFL) student teachers in teaching internship and to what extent the influence was to promote the EFL student teachers' life-long learning to teach. It is a qualitative study with semi-structured group interview as the instrument of the research. The subject of the study was ten EFL student teachers who voluntarily participated in the study from twenty two student teachers. They had enrolled in a microteaching class that applied microteaching lesson study in the sixth semester and then took the teaching internship in the seventh semester. The finding of the study indicates that microteaching lesson study has considerably influences most of the EFL student teachers in gaining life-long learning to teach as they already implemented the steps of microteaching lesson study in their teaching internship initiatively. Finally, this study recommends teacher educators to adapt lesson study in microteaching course that can make the EFL student teachers to keep learning to teach.
\end{abstract}


268 Celt: A Journal of Culture, English Language Teaching \& Literature, Volume 18, Number 2, December 2018, pp. 267 - 281

Key words: microteaching lesson study, EFL student teachers, teaching internship

\begin{abstract}
Abstrak: Kesuksesan lesson study sebagai pendekatan pengembangan profesional guru dalam memperbaiki pembelajaran siswa telah menginspirasi microteaching lesson study yang didesain untuk mahasiswa calon guru di kelas microteaching. Beberapa penelitian menunjukkan bahwa microteaching lesson study membawa dampak positif bagi kemampuan pedagogi dan content knowledge mahasiswa calon guru. Akan tetapi, bagaimana microteaching lesson study mempengaruhi mahasiswa calon guru selama praktek pengalaman lapangan belum ada yang meneliti. Penelitian ini bertujuan mengeksplorasi pengaruh microteaching lesson study pada mahasiswa calon guru bahasa Inggris dalam praktek pengalaman lapangan dan seberapa besar pengaruh tersebut dalam memajukan belajar untuk mengajar sepanjang hayat. Penelitian ini adalah penelitian kualitatif dengan instrumen interview semi struktur. Subjek penelitian berjumlah sepuluh dari dua puluh dua mahasiswa calon guru bahasa Inggris yang berpartisipasi secara suka rela. Mereka telah mengimplementasikan microteaching lesson study di kelas microteaching di semester enam dan telah menyelesaikan praktek pengalaman lapangan di semester tujuh. Hasil penelitian menunjukkan bahwa microteaching lesson study mempengaruhi sebagian besar mahasiswa calon guru bahasa Inggris dalam memperoleh ketrampilan belajar untuk mengajar sepanjang hayat melalui pengimplementasian microteaching lesson study dalam praktek pengalaman lapangan mereka. Penelitian ini memberikan rekomendasi bagi para pendidik calon guru untuk mengadaptasi lesson study dalam perkuliahan microteaching yang dapat membuat mahasiswa calon guru bahasa Inggris tetap belajar untuk mengajar.
\end{abstract}

Kata kunci: microteaching lesson study, mahasiswa calon guru bahasa Inggris, praktek pengalaman lapangan

\title{
INTRODUCTION
}

Being a language teacher requires not only knowledge and skills such as content knowledge and pedagogical knowledge, but also the adaptive character to keep learning to teach. This learning to teach goes through for the whole life in which the process occurs not when ones firstly become teachers; rather such processes have started when they were still students, and continue when they become student teachers learning to be teachers at university. In other 
Suryani, F.B., Rukmini, D., Anggani, D., Bharati, L.,\& Hartono, R. Promo- 269 ting EFL Student Teachers' Life-Long Learning through Microteaching Lesson Study

words, Johnson (2009) states that learning to teach is a long-term, complex, developmental process. Through the process that the student teachers experience during their education and training at unversity, they are expected to be 'adaptive experts who can continue to learn' (Darling-Hammond, 2006, p. 6).

From sociocultural perspective, second language teacher education (SLTE) - the term covers both second and foreign language teacher education views teachers as learners of teaching. They learn to teach by participating in social practices and contexts related to learning and teaching. The participation in language learning and teaching involves interaction in which the key factor to it is in the engagement. Thus, it is significant to design activities that enable student teachers to be actively engaged in learning and teaching. Such activities are present in microteaching lesson study.

Microteaching lesson study is the integration lesson study in microteaching course in which student teachers practice teaching. As it combines microteaching and lesson study, it incorporates as well the elements from both microteaching and lesson study. They include the teaching of small group of peers or real students, the shortened length of teaching time, the division of student teachers into group of three, the cycles of lesson sudy, and the use of video to capture the lesson.

The combination of elements from lesson study and microteaching in microteaching lesson study provides student teachers with circumstances that can engage them in collaborative activities. The engagement enables student teachers to participate in direct experiences as teacher, starting from designing the lesson to teach, then implement it in teaching, until finally reflect on it and revise the lesson plan. As that process is gone through collaboratively rather than individually, it creates a social setting that becomes a prerequisite for the growth of human cognition. In other words, microteaching lesson study provides student teachers with a chance to learn to teach.

Some studies reveal that microteaching lesson study has benefitted the student teachers in learning to teach, improving their content knowledge, pedagogical content knowledge, and technological pedagogical content knowledge (Fernandez and Robinson, 2006; Cavin, 2007; Fernandez 2010; MacDowell, 2010; Molina, 2012). Those benefits were investigated right after the microteaching lesson study was completed. Nevertheless, little is known about the impact of microteaching lesson study when the student teachers enroll in teaching internship, that is when they practice teaching in real 
270 Celt: A Journal of Culture, English Language Teaching \& Literature, Volume 18, Number 2, December 2018, pp. 267 - 281

schools with real students in which they are not obliged to conduct the steps as in microteaching lesson study.

The present study was guided by the following two research questions:

1. Does microteaching lesson study influence the EFL student teachers in their teaching internship?

2. To what extent is the influence of microteaching lesson study in the EFL student teachers in their teaching internship to promote the EFL student teachers' life-long learning to teach?

\section{LITERATURE REVIEW}

\section{A. Microteaching lesson study}

Microteaching lesson study is a modification of lesson study to be used in microteaching course for student teachers. It draws the elements from lesson study. Lesson study is a successful teacher professional development originated in Japan. Lesson study is popular nowadays as it has proven some benefits mainly in improving teachers' instructional strategies, concern about students' need and performance, and collaboration with colleagues (Meyer, 2005; Kim, 2011; Van Sickle, 2011). Some central elements of lesson study maintained in microteaching lesson study, as noted by Fernandez (2008) include an overarching goal for the lesson, collaboration among teachers, the steps of lesson planning, implementation, observation, and revision, and a written reflective report on the lesson study work.

Thus, in microteaching lesson study the student teachers work in group of three to conduct such steps as research lesson planning, teaching and observing, and reflecting and refining the lesson plan. In research lesson planning, the student teachers design the lesson plan together which usually consists of identity of school, grade, semester, topic, skill, time allotment, method, media, and material, steps of teaching, assessment, and student sheet. There is one more feature that must appear in the student teachers' lesson plan in microteaching lesson study that is the anticipation of students' response. It is a prediction of what the students will react on the teacher's steps of teaching. This feature is crucial since one of the focuses in microteaching lesson study is the student learning. During the research lesson planning, the student teachers also discuss what they will observe in the next step. The lesson is then taught by one of the members of the group, while the other two 
Suryani, F.B., Rukmini, D., Anggani, D., Bharati, L.,\& Hartono, R. Promo- 271 ting EFL Student Teachers' Life-Long Learning through Microteaching Lesson Study

members will observe. In the next step, the result from the observation will be discussed and reflected by the group. This step will bring about the points of weaknesses and strengths from the teaching learning process that leads to the refinement of the lesson plan. The result of this process is then written as a reflective report on the work. Then, the other member of the group will teach using the refined lesson plan. The process will thus be iterated again.

Since implemented in microteaching course, microteaching lesson study takes some elements from microteaching as well. These can be found in the reduced class size, the reduced lesson length, and videotaped lesson. The number of student teachers in microteaching is usually small, around 5 to 10 student teachers. The length of the lesson is also reduced from the usual 45 minute teaching time into 15 to 20 minutes. Moreover, the lesson is videotaped for further analysis by student teachers if needed.

\section{B. Sociocultural perspective on SLTE}

Sociocultural perspective views the core of second language teacher education in teachers as learners of teaching. It informs the cognitive and social processes that teachers go through as they learn to teach. Johnson (2009, p. 3) argues that sociocultural perspective provides second language teacher education with "a theory of mind that recognizes the inherent interconnectedness of the cognitive and social, and allows us to see the rich details of how teacher learning emerges out of and is constructed by teachers within settings and circumstances of their work".

Sociocultural perspective also influences second language teacher education in perceiving language teaching. Teaching is seen as creating learning opportunities in which individuals can participate in activities that provide them with direct experiences (Johnson, 2009). Such participation in language learning and teaching involves interaction in which the key factor to it is in the engagement.

Mercer and Littleton (2007) emphasize the important role of engagement with the notion of 'exploratory talk'. It refers to a kind of talk "in which partners engage critically but constructively with each other's ideas" (Littleton \& Mercer, 2010, p. 276). This is in line with Lefstein (2010) who mentions that communication brings the potential sources of tensions between participants, between ideas, and between the concerns raised by each dimension. 
272 Celt: A Journal of Culture, English Language Teaching \& Literature, Volume 18, Number 2, December 2018, pp. 267 - 281

\section{METHODS}

\section{A. Research design}

As the aims of this study were to explore the influence of microteaching lesson study on the EFL student teachers in their teaching internship and to what extent that influence was to promote the EFL student teachers' life-long learning to teach, the design of this study is qualitative. It focused primarily on the EFL student teachers' views of the impact of their microteaching lesson study on their teaching internship program.

\section{B. Context of the study}

This study took place at the English Education Department (EED) of Muria Kudus University. The EED has run a microteaching lesson study in one of the microteaching courses, i.e. microteaching E class. Microteaching is one of the practical courses that is offered for the sixth semester EFL student teachers after they pass some prerequisites courses such as Introduction to Linguistics, Teaching Method for Young Learners, Teaching Methods for Adult Learners, Language Assessment, Language Teaching Media, and so forth. The EFL student teachers enrolled in the six credit microteaching course and learned to teach in front of their peers and real students. Each EFL student teacher was given three chances of practicing teaching: twice in front of their peers, and once in front of real students of secondary schools. Real students of secondary schools here means the students of secondary schools who were willing to come to the microteaching class to be the students taught by the EFL student teachers.

In the next semester, the seventh semester, the EFL student teachers enrolled in teaching internship program, in which they practice teaching in real context of schools. Hence, they have opportunity not only to experience real teaching with real students in schools, but also to gain insights and understanding as to how this profession of English teacher is about. During their teaching internship program, the EFL student teachers were supervised by a practicing teacher from the school and a mentor from their university. None of the supervisors obliged them to do the steps as in microteaching lesson study.

\section{Participants of the study}

All of the research participants in this study have enrolled in microteaching lesson study and have passed the microteaching course. They 
took the teaching internship program in the next semester (the seventh semester) where they taught in practicing schools, either junior high schools or senior high schools. The selection of the research participants was conducted voluntarily which means that only those who were willing to participate in this study were selected. Ten EFL student teachers from three different practicing schools agreed to participate in this study. There were three male participants and seven female participants. The number of female participants exceeded the male ones as this phenomenon is common in English education department.

The participants of this study then signed the consent form explaining that they agreed to be interviewed after they completed their teaching internship. The topic of the study was revealed to the participants, but not the topic of the interview. They just knew it on the day of the interview. The purpose of this is to collect the natural data from participants as whether microteaching lesson study have impact on their teaching internship and to what extent the impact was to promote the EFL student teachers' life-long learning to teach.

\section{Data collection}

Interviews were conducted after the participants completed their teaching internship program. The group interviews were chosen in which the interviewees were divided into two groups and each interview lasted for about one and a half hour. The interview used Indonesian language as the EFL student teachers felt more free to speak up their thoughts using Indonesian. There were only three main questions in the interview including whether microteaching lesson study influence their teaching internship, and if it does, then in what way it influences, and finaly to what extent it influences them regarding the life-long learning to teach. The type of interview conducted was semi-structured one. This means that from those three main questions, the other questions are possible to come up and asked. The interviews were recorded and then transcribed.

\section{E. Data analysis}

The data obtained from the interviews were analyzed qualitatively following Dornyei's (2011). It consists of three steps: transcribing the data, precoding and coding, and interpreting and drawing conclusions. 
274 Celt: A Journal of Culture, English Language Teaching \& Literature, Volume 18, Number 2, December 2018, pp. 267 - 281

\section{FINDINGS}

The participants of this study have enrolled in microteaching lesson study for a semester in their microteaching course. Microteaching lesson study draws the elements from lesson study as well as its steps and give the student teachers the collaborative experience during their microteaching class where they must teach in front of a small group of their peers or real students. The collaborative experience is realized in having the EFL student teachers to work in group of three for their microteaching project. It is also found through the steps of microteaching lesson study starting from designing research lesson together within their group, teaching and observing, and refining the lesson plan.

After completing their microteaching course and passed it, the EFL student teachers joined the teaching internship program in the next seventh semester. This program lasted for three months and required the student teachers to teach in practicing schools, either junior high schools or senior high schools. In each practicing school, there were four to five EFL student teachers. This study aims to investigate whether the experience of microteaching lesson study they had in their microteaching class influences their teaching internship program.

From the ten participants practicing in three different schools, one acknowledged that she did not implement the steps of microteaching lesson study in her teaching internship program. The reason is that the practicing teacher asked her to work individually during the teaching internship although in her practicing school, there were five EFL student teachers. As microteaching lesson study requires collaborative work with other student teachers, the individual work will cause the EFL student teachers not able to implement microteaching lesson study during their teaching internship.

The other nine EFL student teachers noted that they implemented one or more steps of microteaching lesson study in their teaching internship. Some even conducted all the steps although not exactly the same as those in their microteaching course they ever did.

Three students who happened to have their teaching internship in the same practicing senior high school explained that they always had discussion on the lesson plan when they were designing it. Even though they all taught eleventh grade, they must design their lesson plan differently by themselves. However, they chose to discuss their designing lesson plan with their peers as the similarity in the grade they taught. Furthermore, they stated that the 
Suryani, F.B., Rukmini, D., Anggani, D., Bharati, L.,\& Hartono, R. Promo- 275 ting EFL Student Teachers' Life-Long Learning through Microteaching Lesson Study

discussion helped them when they had difficulty with the lesson plan they were planning. They could share ideas one another on such matters as the material for teaching, the methods of teaching, and the media they used. They were also able to seek help from their peers to check their student sheet as some students were criticized by their practicing teacher for the mistakes they made in their student sheet.

They noted that they did it willingly as they have got used to do it since the microteaching lesson study they ever experienced. Nonetheless, their discussion did not include the anticipation of student response which is one of the components that they must prepare in microteaching lesson study. The anticipation of student response is used to predict the likely responses of students to the lesson taught. It is crucial in lesson study because the focus on lesson study is how the students learn. The anticipation of student response enables teachers to plan their lesson completely (Stigler and Hiebert, 1999). The absence of anticipation of student response in the EFL student teachers might be due to the format of lesson plan they designed did not require the anticipation of student response. All lesson plan formats in high schools in Indonesia usually include the information on the school identity, grade, semester, time that teacher teaches, the topic, method of teaching, steps of teaching, material used for teaching, learning sources, assessment, and student sheet. As the anticipation of student response is not stated in the format of the lesson plan they designed, the EFL student teachers did not pay attention to it and focused more on the components in the format they were required.

During the teaching practice, those student teachers also followed the second step of microteaching lesson study, that is implementing the lesson plan and observing their peer practice teaching. They did the observation when one of their peer was teaching. In addition, they video-recorded the process of their peer teaching. The difference of the second step in microteaching lesson study and in the student teachers' teaching internship is that the student teachers did not prepare for their observation sheet. They did not have discussion previously on what to observe when their peer teaching. That's why they did not take a note what they were observing. They said that they just watched and tried to remember what they thought important from their peer teaching. After all, they could play the recorded video if there was something they needed to watch again. This is the reason why they made the video recording of the teaching practice of their peers.

The result of their observation was used as input for improving their lesson plan before they taught their classes. Furthermore, they did reflection 
on their peer teaching. The EFL student teachers explained that the mistakes or flaws that their peers did during their teaching enabled them to learn not to do the same things in their own teaching. Moreover, if they saw that their peers' teaching practice had strengths or it worked well, they could imitate it and apply it for their class. Those input becomes the source for the EFL student teachers to refine and revise their lesson plan. However, the EFL student teachers' reflection on their peer teaching was conducted orally through discussion with their peers. None of them made written reflection on it. This is one of the differences between the reflection in microteaching lesson study and that in the teaching internship. The other difference is found in doing the revision of the lesson plan. The EFL student teachers did not regularly and collaboratively had discussion when doing the revision of their lesson plan. Instead, they often did it individually. The time constraint is the reason for this individual work as everyone might have different schedule. They were not always able to gather to discuss their lesson plan revision with their peers. For this reason, having it done individually becomes the solution in the teaching internship.

The findings of this study shows that microteaching lesson study in the microteaching course have influence on the teaching internship of the EFL student teachers. This is clearly seen from the fact that some EFL student teachers initiated to implement the steps of microteaching lesson study in the teaching internship on their own. They willingly did that without any force or obligation from their mentor or practicing teacher. This indicates that the EFL student teachers receive benefits from their previous experience of microteaching lesson study that urge them voluntarily to conduct it again in their teaching internship program. Furthermore, the complex nature of teaching internship becomes one of the influential factors that makes the EFL student teachers to implement the steps of microteaching lesson study in their teaching internship.

Some previous studies reveal that microteaching lesson study brings advantages for student teachers regardless of their fields of study. Fernandez and Robinson (2006) reported that microteaching lesson study is beneficial to the secondary mathematics pre-service teachers learning to teach. The recent research by Fernandez (2010) showed that mathematics pre-service teachers' engagement in microteaching lesson study deepened their understanding of the content and enhanced their ability to teach. Molina (2012) stated that elementary pre-service teachers participating in microteaching lesson study grew in content knowledge as well as pedagogical content knowledge. This finding is in alignment with MacDowell's (2010) that shows pre-service 
Suryani, F.B., Rukmini, D., Anggani, D., Bharati, L.,\& Hartono, R. Promo- 277 ting EFL Student Teachers' Life-Long Learning through Microteaching Lesson Study

teachers deepened their pedagogical content knowledge after experiencing microteaching lesson study.

Even though this study does not investigate the benefits of microteaching lesson study that the EFL student teachers received, they benefitted from microteaching lesson study as they continued to conduct the steps in microteaching lesson study during their teaching internship. As a matter of fact, the findings showed that the EFL student teachers also experienced such benefits when they had their teaching internship.

One of the benefits that EFL student teachers attained is having input and feedback from their peer student teachers. One student teacher stated that when she had difficulty with lesson plan, having discussion with her peers could help her to solve her problems. Not only she could gain input from her peers, but she also could see from different angles that her peers view. This raises awareness and adds new perspectives that enrich her knowledge and skill. Another student teacher mentioned that the feedback that she got from her peers on her teaching performance helped her improve her next teaching performance. This is in line with Richards and Farrel (as cited in Day, 2013, p. 2) who explains that one of the benefits of peer observation is 'helping narrowing the gap between a teacher's imagined view of teaching and what actually happens'. Moreover, the collaboration experience helps student teachers in making a lesson work for their students (Cavin, 2007). In other words, the EFL student teachers felt that their content knowledge and pedagogical knowledge were improved through the collaborative steps of lesson study in their teaching internship.

The other factor that might motivate the EFL student teachers to implement the steps of microteaching lesson study in their teaching internship is that the complex environment and problems the EFL student teachers encounter when teaching the real students in real schools as in the practicing schools. This condition is very much different compared to teaching a small group of their peers in microteaching class in their university. In the teaching internship, the EFL student teachers act as real teachers with real students in real schools. Their position and responsibility are considered the same as other teachers in those schools. In Darling-Hammond's $(2006$, p. 6) term, they 'learn not only to "think like a teacher" but also to "act as a teacher"'. Therefore, they need to have better preparation and actions to be able to face the problems that might appear during their teaching internship. Therefore, implementing the steps of microteaching lesson study in their teaching internship becomes their solution to deal with the complexity and problems of the teaching 
278 Celt: A Journal of Culture, English Language Teaching \& Literature, Volume 18, Number 2, December 2018, pp. 267 - 281

internship program. By facing it together with their peers in a structured way like the steps of microteaching lesson study, those EFL student teachers definitely engage in a meaningful collaborative experience.

The engagement in the collaborative works like in microteaching lesson study can be a powerful source for the EFL student teachers to face the complexities of the teaching internship. It provides the student teachers with what Singh and Richards (2009, p. 202) calls 'communities of practice' which 'grant a primary place to the social activities being engaged in'. In these communities of practice, the EFL student teachers are given opportunities to learn to teach where they are welcome to make mistakes and have flaws and at the same time get a chance to improve them. Through the step of reflecting and refining, the EFL student teachers can learn that it is fine and accepted if their teaching does not run as they already plan because they can reflect on it and refine it to make a better teaching. This helps them to avoid the desperate feeling when dealing with the problematic new teaching situation in real schools. Instead, it fosters a conducive circumstance that makes them persistent and resilient to keep learning to teach not only after they complete their teaching internship, but also when they have become real teachers in the future.

From the sociocultural perspective, such collaborative engagement contributes significantly to the formation of human cognition. As Johnson (2009, p. 3) notes, "teacher learning emerges out of and is constructed by teachers within settings and circumstances of their work". It is not transmitted from mentor to student teachers as held by traditional perspective on second language teacher education. Moreover, teaching is seen as creating learning opportunities in which individuals can participate in activities that provide them with direct experiences (Johnson, 2009). Such participation in language learning and teaching involves interaction in which the key factor to it is in the engagement.

The steps of microteaching lesson study have rich setting and circumstances that enable the EFL student teachers to construct their learning to teach. All the steps of microteaching lesson study offer active participation from its members to interact in discussion, debate, and sharing. The first step of planning the lesson requires the student teachers to sit together to discuss how the lesson will be designed. They also must plan the focus of the observation that they will conduct in the second step. In the third step after teaching and observing, they again gather to see how the lesson goes as the plan. They do the reflection and finally make substantial changes to the lesson 
Suryani, F.B., Rukmini, D., Anggani, D., Bharati, L.,\& Hartono, R. Promo- 279 ting EFL Student Teachers' Life-Long Learning through Microteaching Lesson Study

plan for the next teaching. Wilson and Peterson (2006) state that "the social occasions of conversation, discussion, joint work, and debate also play a critical role in learning". In other words, Wilson and Peterson (2006) highlight that we learn by participating in groups as found in microteaching lesson study.

The implementation of the steps of microteaching lesson study in the EFL student teachers' teaching internship enables them to construct their knowledge of learning and teaching that affect the formation of cognition. It is the key to learning to teach which they need for their future career as English teachers. Learning to teach is a life-long learning because being a teacher necessitates to learn for the whole of life. The fast changing of world nowadays inevitably affects the classroom as well as the teaching. Consequently, this requires English teachers to keep learning to teach. Microteaching lesson study has helped shaping the spirit and good habits of the EFL student teachers to continuing learning to teach through their conducting it in their teaching internship.

\section{CONCLUSION}

The EFL student teachers have implemented the steps of microteaching lesson study in their teaching internship because they have benefited from their microteaching lesson study when they had it in their microteaching course. In addition, the complexity of teaching internship becomes another factor for the EFL student teachers to conduct microteaching lesson study during their teaching internship. Even though the implementation of microteaching lesson study in the teaching internship is not exactly the same as that in the microteaching course, the differences found are only slight. In the teaching internship, the EFL student teachers paid less attention to things dealing with administration. These include the absence of the anticipation of students' response in the format of the lesson plan and during the discusson in lesson planning, the absence of observation sheet for observing the teaching, and the absence of the written reflection. Compared with similarities of microteaching lesson study that the EFL student teachers had conducted in the teaching internship, the absence of the administration do not strongly affect the benefits that the EFL student teachers gain from the process.

Regarding that the EFL student teachers have implemented the steps of microteaching lesson study twice in their microteaching course and in teaching internship, this fact reveals that microteaching lesson study influences the EFL student teachers' teaching internship. Likewise, this reveals that microteaching 
280 Celt: A Journal of Culture, English Language Teaching \& Literature, Volume 18, Number 2, December 2018, pp. 267 - 281

lesson study implemented in the teaching internship promotes the life-long learning to teach of the EFL student teachers. This learning to teach spirit and habits are crucial for EFL student teachers to grow and develop their teaching professionality as well as to adapt with the complexity of the teaching world. Accordingly, this study offers insight for teacher educators in preserving the spirit of life-long learning to teach of their EFL student teachers through microteaching lesson study in microteaching course. The benefits that the EFL student teachers attain will motivate them to continue having it during their teaching internship. Finally, this can promote their spirit of learning to teach that will endure when they become English teachers.

\section{REFERENCES}

Cavin, R. M. (2007). Developing technological pedagogical content knowledge in preservice teachers through microteaching lesson study. The Florida State University.

Darling-Hammond, L. (2006). Constructing 21st-century teacher education. Journal of teacher education, 57(3), 300-314.

Day, R. R. (2013). Peer Observation and Reflecting in the ELT Practicum. Dil ve Edebiyat Egittimi Dergisi, 8, 1-8.

Dornyei, Zoltan. 2011. Research Methods in Applied Linguistics. Oxford: Oxford University Press.

Fernandez, M. L. (2008). Developing Knowledge of Teaching Mathematics through Cooperation and Inquiry. Mathematics teacher, 101(7), 534-538.

Freeman, D., \& Johnson, K. E. (1998). Reconceptualizing the knowledge-base of language teacher education. TESOL quarterly, 32(3), 397-417.

Johnson, K. E. (2009). Second language teacher education: A sociocultural perspective. New York: Routledge.

Kim, J. Y. (2011). A case study of lesson study in a high school: Implementation after the initial funding cease (Doctoral dissertation, University of Illinois at Urbana-Champaign).

Littleton, K. \& Mercer, N. (2010). The significance of educational dialogues between primary school children. In K. Littleton \& C. Howe (Eds.). 
Suryani, F.B., Rukmini, D., Anggani, D., Bharati, L.,\& Hartono, R. Promo- 281 ting EFL Student Teachers' Life-Long Learning through Microteaching Lesson Study

Educational Dialogues: Understanding and Promoting Productive Interaction (pp. 271-288). London: Routledge.

MacDowell, A. (2010). Preservice teachers' use of lesson study in teaching nature of science (Doctoral dissertation, Georgia State University).

Mercer, N., \& Littleton, K. (2007). Dialogue and the development of children's thinking: A sociocultural approach. London: Routledge.

Mergler, A. G., \& Tangen, D. (2010). Using microteaching to enhance teacher efficacy in pre-service teachers. Teaching Education, 21(2), 199-210.

Meyer, R. D. (2005). Lesson study: the effects on teachers and students in urban middle schools. (Doctoral dissertation, Baylor University).

Molina, R. V. (2012). Microteaching lesson study: Mentor interaction structure and its relation to elementary preservice mathematics teacher knowledge development. (Doctoral Dissertation, Florida International University).

Singh, G. \& Richards. (2009). Teaching in the course room. In A. Burns \& J. C. Richards (Eds.), The Cambridge guide to second language teacher education (pp. 201-208). New York: Cambridge University Press.

Stigler, J. W., \& Hiebert, J. (1999). The teaching gap: Best ideas from the world's teachers for improving education in the classroom. New York: Free Press

Van Sickle, J. A. (2011). Lesson study's impacts on teacher perception of efficacy in teaching (Doctoral dissertation, Humboldt State University).

Wilson, S. M., \& Peterson, P. L. (2006). Theories of Learning and Teaching: What Do They Mean for Educators? Working Paper. National Education Association Research Department. 